\title{
Growth and biomass yield response of clover (Trifolium decorum) to preceding crop and organic treatment in the highlands of Awi Administrative Zone, Ethiopia
}

\author{
Agegnehu Shibabaw ${ }^{1}$, Getachew Alemayehu ${ }^{1}$, Enyew Adgo ${ }^{1}$, Jörn Germer ${ }^{3}$, Folkard Asch ${ }^{3}$ and \\ Bernhard Freyer ${ }^{2}$ \\ ${ }^{1}$ Bahir Dar University (BDU), College of Agriculture and Environmental Sciences, Ethiopia \\ ${ }^{2}$ University of Natural Resources and Life Sciences (BOKU) Vienna, Austria \\ ${ }^{3}$ University of Hohenheim (UHOH), Germany
}

\begin{abstract}
Low soil fertility status is a dominant challenge in Ethiopian agriculture for decades. Organic amendment from different sources could help to rebuild the soil fertility status of the country. Hence, an experiment was conducted to evaluate the outcome of organic treatment and preceding crops on growth and biomass yield of clover. Four levels of organic treatments $\left(\mathrm{V} 1=0 \mathrm{t} \mathrm{ha}^{-1} \mathrm{FYM}\right.$; V2 $=5 \mathrm{t} \mathrm{ha}^{-1} \mathrm{FYM}$; V3 $=2.5 \mathrm{tha}^{-1} \mathrm{FSB}$ and V4 $=5 \mathrm{t} \mathrm{ha}^{-1}$ $\left.\mathrm{FYM}+2.5 \mathrm{tha}^{-1} \mathrm{FSB}\right)$ and two levels of crop rotation patterns $\left(\mathrm{R} 1=\right.$ wheat - clover and $\mathrm{R}_{2}=$ potato-clover) were factorially arranged and laid out in a completely randomized block design (RCBD) with four replications. Plant height, number of tillers plant ${ }^{-1}$, number of nodules plant ${ }^{-1}$, root biomass plant ${ }^{-1}$ and above ground biomass of clover was recorded and analyzed using SAS system. The overall experimental results showed that only the main effect of organic amendment had a significant effect on the growth and biomass yield of clover. The highest total dry biomass $\left(5.6 \mathrm{t} \mathrm{ha}^{-1}\right)$ of clover was recorded at $5 \mathrm{t} \mathrm{ha}^{-1} \mathrm{FYM}+2.5 \mathrm{tha}^{-1} \mathrm{FSB}$. The unfertilized control gave the lowest mean dry biomass $\left(3.06 \mathrm{t} \mathrm{ha}^{-1}\right)$ of clover compared to all other treatments. Thus, $5 \mathrm{t} \mathrm{ha}^{-1} \mathrm{FYM}+2.5 \mathrm{t} \mathrm{ha}^{-1}$ FSB could be recommended for better biomass yield of clover. The finding could bridge the chronic green manure and livestock feed shortage of the district.
\end{abstract}

Keywords: Clover, biomass yield, preceding crops, farmyard manure

DOI: http://dx.doi.org/10.4314/ejst.v10i3.1

\section{INTRODUCTION}

Declining of soil fertility and food security status are recurrent problems in Sub-Saharan Africa. Continuous cultivation without or limited application of organic inputs into the soil and conventional rotation system are the causes of soil fertility and productivity decline (Zingore, 2011). In addition, limited incorporation of organic matter inputs into soil during the past 50 years has led to a deterioration in soil structure and health (Carl et al., 2007). Hence, proper application of organic matter into the soil is advised to enhance soil fertility, which increases crop productivity.

Organic matter amendments are essential for the sustainability of long-term productivity of agroecosystems through improving the physical, chemical and biological properties of the soil. Organic amendment improves soil nutrients level, soil water holding capacity, soil reaction $(\mathrm{pH})$,

\footnotetext{
*Corresponding author: agegnehus@hotmail.com

(C) This is an Open Access article distributed under the terms of the Creative Commons Attribution License (http://creativecommons.org/licenses/CC BY4.0).
} 
movement of water and air, activities of soil microbes, soils tilth, root growth and penetration of crops, all of which ultimately improve the productivity of crop (Scotti, 2015).

The effect of organic matter application on growth and yield of legume crops and forages was reported by several researchers. For instance, application of farmyard manure at $7.5 \mathrm{t} \mathrm{ha}^{-1}$ produced a higher dry pod yield $\left(3510 \mathrm{~kg} \mathrm{ha}^{-}\right.$ 1) of faba bean as compared to the applications of recommended dose of NPK fertilizers that gave $2970 \mathrm{~kg} \mathrm{ha}^{-1}$ dry pod yield (Sulfab, 2010). Similarly, Yolcu et al. (2010) reported that cattle manure at $40 \mathrm{t} \mathrm{ha}^{-1}$ gave higher yield, quality and mineral content of common vetch compared to the control. Hellal and Zewainy (2014) showed that organic fertilizer application in combination with bio-fertilizers not only improved the yield, nutrient availability and uptake of faba bean markedly, but also improved maize productivity in the succeeding season more stable than the application of mineral fertilizer. Sulfab (2010) recommended that application of organic fertilizers at $15 \mathrm{t} \mathrm{ha}^{-1}$ with Rhizobium seed inoculation significantly increased groundnut pod and hay yields over the control. Tarkalson et al. (1998) recommended that application of manure at $10 \mathrm{tha}^{-1}$ would facilitate mycorrhizal colonization in dry bean roots which might in turn improve the availability of phosphorous and its uptake by plants. Konthoujam et al. (2013) identified that the number of nodules per plant would be influenced significantly by the different combination of organic materials and Rhizobium inoculants. Generally, recent studies showed that organic matter applications give tremendous yield advantage on ranges of tropical and temperate crops.

In addition, to organic matter application, a preceding crop has widely been recognized as an important alternative method in improving the potential yield of the succeeding crops. According to Angus et al. (2001), Dalal and Mayer (1990) the yield of wheat increased by an average of 40 to $50 \%$ following pulses as preceding crops. Kumar and Hiremath (2015) reported that 39\% yield increment in maize was recorded using chickpea as a preceding crop. Similarly, Armstrong et al. (1999) also reported that grain protein and yield of sorghum increased by up to $5 \%$ and $70 \%$, respectively, following mung bean as a preceding crop.

This article examined the impact of different organic amendments and of preceding crops on the biomass yield of clover (Trifolium decorum) in the climatic and soil conditions of the highland area of Awi Administrative Zone. The research aimed to assess the contribution of clover to solve the key challenges of agriculture in many agro-ecological zones of Sub-Saharan Africa. Clover provides high quality and quantity feed, restoration of soil fertility due to the improvement in carbon sequestration, deep root penetration, high root biomass and its ability to fix nitrogen biologically. However, due to poor agronomic management practices and improper soil management system, biomass yield of clover varies considerably from region to region. Farmers of the locality have little experience in cultivating clover with the use of organic inputs. They rather grow clover in their pasture land and between farmlands as a source of feed and green manure. In view of these, the present study was initiated to determine the effect of a preceding crop and different level and type of organic matter applications on growth parameters and biomass yield of clover in the highlands of Awi Administrative Zone. . 


\section{MATERIALS AND METHODS}

\section{Descriptions of the Study Area}

The study was conducted both on station at farmers' training center and on farm at individual farmers' cropping field in Guagusa district from 2013 to 2014. Guagusa district is located between $11^{\circ} 92^{\prime}$ to $11^{\circ} 91^{\prime} \mathrm{N}$ latitude and $28^{\circ} 61^{\prime}$ to $28^{\circ} 87^{\prime} \mathrm{E}$ longitudinal ranges. The altitude of the study sites ranges from $2451 \mathrm{~m}$ to $2537 \mathrm{~m}$ above sea level, and their slopes range from $2.6 \%$ to $3.7 \%$. The temperature of the area varies between $10.2{ }^{\circ} \mathrm{C}$ and $22.4{ }^{\circ} \mathrm{C}$. The average mean annual rainfall is $2491.9 \mathrm{~mm}$ with uni-modal rainfall pattern. The rainy months extend from March to the end of November. Peak rainfall occurs during the months of July and August when maximum potential of crop production is possible. The dominant soil category of the district is Nitosols without consolidated evidence on its $\mathrm{pH}$, total $\mathrm{N}$, organic matter, $\mathrm{C}$ : $\mathrm{N}$ and other properties of the soil ( Yihenew Gebreslasie, 2002). Nitosols is a deep, red and well drained soil with high agricultural potential that is common in the majority of highlands in Ethiopia.

The farming system of the area is mixed type: Both crop production and livestock managements are integrally conducted. Crops such as potato, wheat, barley, maize, field pea and faba bean are dominantly grown accounting $90 \%$ of the cultivated land while cattle, sheep, horse, mule and poultry husbandry is predominantly practiced in the study zone (ANRS-BoFED, 2006).

\section{Treatments and Design}

Four levels of organic treatment and two levels of proceeding crop were factorially arranged in randomized complete block design (RCBD) with four replications. The organic matter treatments were: $\mathrm{V} 1=0 \mathrm{t} \mathrm{ha}^{-1}$ farmyard manure; $\mathrm{V} 2=5 \mathrm{tha}^{-1}$ farmyard manure; V3 $=2.5 \mathrm{t} \mathrm{ha}^{-1}$ fresh sesbania biomass and V4 $=5 \mathrm{t} \mathrm{ha}^{-1}$ farmyard manure $+2.5 \mathrm{t}$ $\mathrm{ha}^{-1}$ fresh sesbania biomass. The rotation patterns were: $\mathrm{R}_{1}=$ wheat - clover and $\mathrm{R}_{2}=$ potato-clover. Manure was uniformly surface broadcasted and then incorporated within $20 \mathrm{~cm}$ soil depth two weeks before planting. The size of the plot was $3 * 3 \mathrm{~m}$ with a net plot size of $2.8 * 2.8 \mathrm{~m}$. The distance between plots and replications was 50 and $100 \mathrm{~cm}$, respectively. The seed of the most adaptive Ethiopian clover (Trifolium decorum) was used with drill planting and row spacing of $20 \mathrm{~cm}$. The crop was planted on the $17^{\text {th }}$ and the $18^{\text {th }}$ of June 2014 and harvested on the $22^{\text {nd }}$ and the $23^{\text {rd }}$ of September 2014.

Soil Analysis: Soil samples were taken at plow depth of $0-20 \mathrm{~cm}$ using an auger. Four soil samples were taken diagonally on each experimental site. Each soil sample was mixed together into a composite sample and prepared for analysis. Samples were subjected to drying, grinding, mixing, partitioning and sieving before undergoing physicochemical analysis. Samples of each soil were analyzed following standard soil analysis methods. Particle size distribution was determined by hydrometer method (Bouyoucos, 1962). Soil pH was measured using a digital $\mathrm{pH}$ meter in a 1:2.5 soil-water suspension while organic carbon (OC) was determined by wet digestion method (Walkley and Black, 1934). Determination of total $\mathrm{N}$ of the soil was carried out through Kjeldahl digestion method (Black and Allison, 1965). Available phosphorus was examined calorimetrically using Olsen et al.( 1954). Exchangeable potassium was determined by flame photometer as described by McLean 
(1965). Titration method was applied to determine Cations Exchange Capacity (CEC) while the bulk density of the soil was determined by weighting oven dried soil (at $105^{\circ} \mathrm{C}$ for $24 \mathrm{hrs}$ ) divided by the core volume ( $98.123 \mathrm{~cm}$ cubic).

\section{Agronomic data collection and analysis}

The growth and biomass yield parameters of clover (Trifolium decorum) such as plant height, number of nodules, number of tillers, root and above ground biomass of clover were all measured and recorded regularly. The root and above ground biomass of clover was also recorded after drying with $75^{\circ}$ for 24 hours in an oven. Data were subjected to analysis of variance (ANOVA) using general linear model (GLM) procedures, SAS version 9.1. Means of data were separated using the Least Significant Difference (LSD) test at $5 \%$ level of significance. Correlation analysis was also performed to study the nature and degree of relationship between growth parameters and yield attributes of clover with Pearson correlation procedure using SAS software.

\section{RESULTS AND DISCUSSION}

\section{Initial soil physico-chemical properties of experimental site}

The means over site initial physicochemical properties of the experimental sites are indicated below. The soil textural class was clay loam with mean particle size distribution of $36.6 \%$ clay, $34.4 \%$ silt and $29 \%$ sand. The bulk density of the soil was $1.37 \mathrm{~g} \mathrm{~cm}^{-3}$ with moderately compacted soil. The chemical properties were with means of $1.26 \%$ organic carbon (OC), $0.12 \%$ total nitrogen $(\mathrm{N}), 8.64 \mathrm{ppm}$ phosphorus
(P), $0.68 \mathrm{cmol} \mathrm{(+)} \mathrm{kg}^{-1}$ of soil potassium (K), 5.19 of $\mathrm{pH}$ and $15.64 \mathrm{cmol}^{+}+\mathrm{kg}^{-1}$ of soil CEC. This implies that the experimental soil apparently contains low levels of soil quality parameters initially to support plant growth (Table 1). This is in agreement with standardizations of Murphy (2007) who categorized a soil with $\mathrm{pH}$ (5.19) as strongly acidic and organic carbon with $1.26 \%$ as low in standards. Similarly, $0.12 \%$ nitrogen, $8.64 \mathrm{ppm}$ phosphorus and $0.678 \mathrm{cmol}(+) \mathrm{kg}^{-1}$ of soil potassium concentrations of the soil were categorized as low and the cation exchange capacity $\left(15.64 \mathrm{cmol}(+) \mathrm{kg}^{-1}\right.$ of soil $)$ of the soil was moderate with compacted level of soil bulk density $\left(1.37 \mathrm{~g} \mathrm{~cm}^{-3}\right)$ (Hazelton and Murphy, 2007).

\section{Manure chemical concentrations}

Farmyard manure was produced with mixtures of fresh cow dung (55\%), sheep dung (35\%), chicken waste $(5 \%)$ and tree lucerne as bedding material $(5 \%)$. Then at maturation, the organic manure was analyzed for the nutrient concentration by collecting composite sample from all depths at top, middle and base of the pit. Green manures were collected and dried in a closed door to avoid nutrient volatilization. The nutrient concentration recorded were $28.12 \%$ organic matter, $1.20 \%$ total nitrogen, $0.65 \%$ total phosphorus and $1.1 \%$ total potassium from farmyard manure. Equivalent results were observed in Ethiopia by Lupway and Girma Adugna (2010) who reported that depending on the nature of substrate farmyard manure provides on average $2.1 \%$ potassium, $1.83 \%$ nitrogen, $1.64 \%$ of phosphorus and $11.98 \%$ organic carbon. In addition, green manures contained substantial plant nutrients to support plant growth. Sesbania green manure contained $2.42 \%$ nitrogen, $0.32 \%$ total phosphorus and $0.91 \%$ total potassium (Table 2 ). 
Table 1: Initial physicochemical properties of the experimental soil before commencing the study

\begin{tabular}{lccccccc}
\hline Soil parameters & Station & $\begin{array}{c}\text { On-farm } \\
\text { Site- } 1\end{array}$ & $\begin{array}{c}\text { On-farm } \\
\text { site }-2\end{array}$ & $\begin{array}{c}\text { On-farm } \\
\text { Site- } 3\end{array}$ & $\begin{array}{c}\text { On-farm } \\
\text { Site- } 4\end{array}$ & Means & Category \\
\hline Total nitrogen $\%$ & 0.13 & 0.11 & 0.12 & 0.10 & 0.14 & 0.12 & low \\
Available $\mathrm{P}(\mathrm{PPM})$ & 9.54 & 8.44 & 8.98 & 7.84 & 9.30 & 8.64 & low \\
Exc. $\mathrm{K} \mathrm{cmol}(+) \mathrm{kg}^{-1}$ soil & 0.68 & 0.65 & 0.65 & 0.70 & 0.71 & 0.68 & low \\
Organic carbon $(\%)$ & 1.30 & 1.23 & 1.22 & 1.23 & 1.32 & 1.26 & low \\
Organic matter $(\%)$ & 2.25 & 2.15 & 2.14 & 2.17 & 2.36 & 2.21 & low \\
pH $\left(\mathrm{H}_{2} \mathrm{O}\right)$ & 5.36 & 5.17 & 5.12 & 4.90 & 5.41 & 5.19 & moderate \\
CEC cmol $(+) \mathrm{kg}^{-1}$ soil & 16.10 & 14.08 & 16.66 & 13.96 & 17.40 & 15.64 & moderate \\
Bulk density g cm ${ }^{-3}$ & 1.36 & 1.37 & 1.38 & 1.39 & 1.35 & 1.37 & compacted \\
\hline Sand & 27.00 & 29.00 & 30.00 & 30.00 & 29.00 & 29.00 & \\
Clay & 38.00 & 37.00 & 36.00 & 34.00 & 38.00 & 36.60 & \\
Silt & 35.00 & 34.00 & 34.00 & 36.00 & 33.00 & 34.40 & \\
Textural class & clay loam & Clay & clay & clay & Clay & clay & \\
\hline
\end{tabular}

$\mathrm{CEC}=$ Cation exchange capacity; $\mathrm{P}=$ phosphorus; $\mathrm{K}=$ potassium; $\mathrm{ppm}=$ part per million and $\mathrm{pH}=$ potential of hydrogen

Table 2: Chemical composition of different manure sources

\begin{tabular}{lccccccc}
\hline Manure type & $\mathbf{p H}$ & $\begin{array}{c}\text { CEC cmol } \\
(+) \mathrm{kg}^{-1} \text { soil }\end{array}$ & $\mathbf{O C} \%$ & $\mathbf{O M \%}$ & $\mathbf{N \%}$ & $\mathbf{P \%}$ & $\mathrm{K} \%$ \\
& & & & & & \\
\hline Farmyard manure & 7.44 & 44.2 & 16.31 & 28.12 & 1.20 & 0.65 & 1.1 \\
Sesbania (Sesbania sesban) & & & & & 2.42 & 0.32 & 0.91 \\
\hline
\end{tabular}

$\mathrm{CEC}=$ Cation exchange capacity; $\mathrm{N}=$ nitrogen; $\mathrm{P}=$ Phosphorus; $\mathrm{K}=$ potassium; $\mathrm{pH}=$ potential of hydrogen; $\mathrm{OM}=$ organic matter and $\mathrm{OC}=$ organic carbon

\section{Growth parameter and biomass yield improvement}

The overall combined experimental results indicated that the main effect of preceding crops (factor B) and the interaction effects of organic matter application and preceding crop (AXB) did not show any significant effect on the growth and biomass yield of clover. Nor did plant height, number of tillers, number of nodules, dry root and shoot biomass show significant variation in response to the variation of either the preceding crop or their interactions with organic treatments. A similar trend was followed in all 
other parameters except in the interaction (AXB) effects of the root and shoot biomass at station condition. However, the main effect of organic matter applications (factor A) has a significant effect on the growth and biomass yield of clover at both sites and combined over sites. Statistically, significant differences were observed among these treatments with respect to all the parameters measured. Generally, application of $5 \mathrm{t} \mathrm{ha}^{-1}$ FYM $+2.5 \mathrm{t} \mathrm{ha}^{-1}$ FSB was found superior in almost all parameters measured followed by $5 \mathrm{t} \mathrm{ha}^{-1} \mathrm{FYM}$, $2.5 \mathrm{t} \mathrm{ha}^{-1} \mathrm{FSB}$ and the unfertilized control. The control has shown the lowest in all the growth parameters and biomass yield compared to all other treatments (Table 3, 4, 5).

\section{Growth parameter}

Plant height $(\mathrm{PH})$ was not significantly affected by preceding crops and their interaction with organic matter application in all sites and the combined over sites. However, statistically significant $(p<0.01)$ plant height was recorded in response to the main effect of different levels of organic matter application. The tallest plant height of 57.05 and $51.00 \mathrm{~cm}$ was recorded by the application of $5 \mathrm{t} \mathrm{ha}^{-1} \mathrm{FYM}+2.5 \mathrm{t} \mathrm{ha}^{-1} \mathrm{FSB}$ at station and onfarm conditions, respectively. The unfertilized control showed the shortest plant height of 39.25 and $37.38 \mathrm{~cm}$ at station and on-farm conditions, respectively. The combined over sites data also showed that the tallest plants height (54.02 $\mathrm{cm}$ ) was recorded at $5 \mathrm{t} \mathrm{ha}^{-1} \mathrm{FYM}+2.5 \mathrm{t} \mathrm{ha}^{-1}$ FSB compared to all other treatments (Table 5). The increases in plant height are attributed to increased level of nutrients, organic carbon and microbial activity from mixed sources of organic treatments. This is in agreement with the findings of Adeoye et al. (2011) such that combination of green and FYM resulted in better plant height than the unfertilized control did. Malligawad ( 2010) also noted that application of manure brought about significantly better plant height of fodder than unfertilized control did.

Like plant height, number of tillers (TN) per plant was not significantly affected by the preceding crops and their interaction with organic matter application. However, statistically significant response was recorded in response to different levels of organic treatments at both sites and the combinations over sites. Application of FYM at 5 $\mathrm{t} \mathrm{ha}^{-1}+\mathrm{FSB} 2.5 \mathrm{t} \mathrm{ha}^{-1}$ showed superior numbers of tillers plant ${ }^{-1}$ of $4.5 \& 4.6$ at station and on-farm conditions, respectively, than all other treatments did. Consequently, the lowest mean number of tillers was recorded on unfertilized control. The combined over site data also showed that FYM at $5 \mathrm{t} \mathrm{ha}^{-1}+\mathrm{FSB} 2.5 \mathrm{t} \mathrm{ha}^{-1}$ gave superior number of tillers (4.57) than the rest of treatments. Following this treatment, $5 \mathrm{t} \mathrm{ha}^{-1} \mathrm{FYM}$ also demonstrated greater number of tillers plant ${ }^{-1}$ (4) in combined over sites (Table 5). The unfertilized control provided the least number of tillers plant ${ }^{-1}$ (1.94) compared with the rest of treatments. This is due to the improvements of soil physical and chemical properties up on the use of organic treatments. The current result has parallels with the previous study of Bilal (2000) in that application of FYM increased the number of tillers of motto grass over control. Yolcu et al. (2011) also suggested that the combination of manure at $40 \mathrm{t} \mathrm{ha}^{-1}$ gave higher tiller number, biomass yield, quality and mineral content of common vetch compared to the control. Sulfab (2013) reported that application of organic fertilizers at $15 \mathrm{t} \mathrm{ha}^{-1}$ significantly increased the tillering capacity and hay yields of groundnut over the control. 


\section{Number of nodules}

Number of nodules (NN) was not significantly affected by the preceding crops and their interaction with organic matter application. However, statistically significant $\quad(p<0.01)$ difference was recorded in response to the main effect of the different levels of organic matter application (Table 4, 5 and 6). Application of $5 \mathrm{t}$ ha $^{-1}$ FYM +2.5 t ha $^{-1}$ FSB led to significantly greater effective number of nodule plant ${ }^{-1}$ of 28 and 28.25 at station and on-farm conditions, respectively. Similarly, the combined over site data showed that the highest number of nodule plant $^{-1}$ (28.13) was recorded from the combined application of $5 \mathrm{t} \mathrm{ha}^{-1} \mathrm{FYM}+2.5 \mathrm{t} \mathrm{ha}^{-1}$ FSB. Following this treatment, $5 \mathrm{t} \mathrm{ha}^{-1}$ of FYM showed more number of nodule (27.01) following the highest level of organic treatment. The lowest number of nodules plant ${ }^{-1}$ (20.3) was recorded by untreated check (Table 5). FSB at $2.5 \mathrm{t} \mathrm{ha}^{-1}$ led to an intermediate number of nodules plant $^{-1}$ (21.82) which is slightly higher compared to the unfertilized control.

The highest number of nodule plant ${ }^{-1}$ was due to the increased level of phosphorous and other soil nutrients upon the use of organic amendments. This is in line with previous reports of Madukwe et al. (2008) in that organic manure positively influenced the nodulation of the cowpea varieties. Consequently, poultry manure gave the highest number of nodules plant ${ }^{-1}$ (15.9) which was significantly different from the mean values of 12.2 and 10.3 nodules plant ${ }^{-1}$ observed from cow dung-treated plots and untreated plots, respectively. Abebe Zerihun et al. (2011) reported that greater number of nodules of cowpea was recorded upon the use of integrated soil fertility management than the unfertilized control. According to Otieno et al. (2009) application of manure improved the nodulation number plant ${ }^{-1}$ of cowpea in the short rainy seasons. Tarkalson et al. (1998) suggested that application of manure to subsoils would facilitate mycorrhizal colonization in dry bean roots grown compared with untreated control. Konthoujam et al. (2013) also found out that the number of nodules plant ${ }^{-1}$ was influenced significantly by the different combination of organic materials and that nodulation increased depending on the type of organic amendments. 
.

衰哭

要

产

龍

$\stackrel{20}{3}$

赔

政

旅

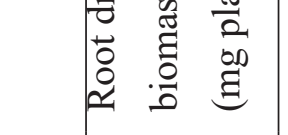



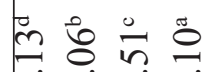

究

ñ.

$\ddot{8}$

을

变

可

五壳臀

$\pm$

$$
\text { 言 }
$$

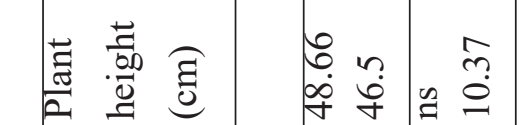

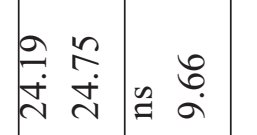



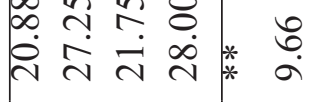

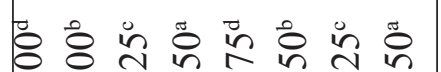

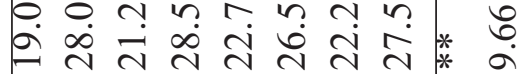

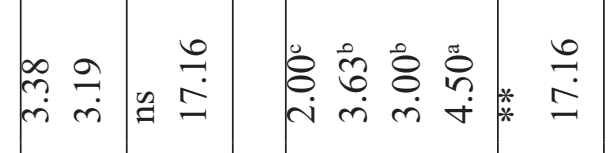

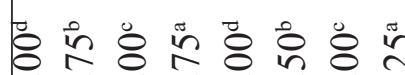

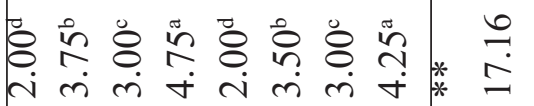

กุ

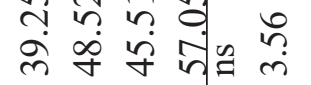



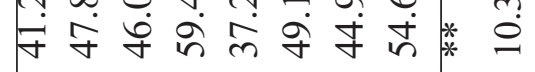

(2)

bo

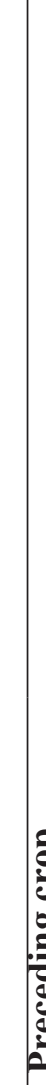

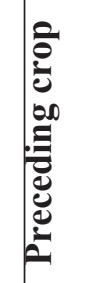

๘ 光

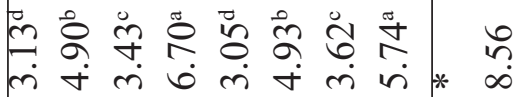

荀

:

๘

in

$\ddot{n}$

$\dot{\nabla}$

क

节

泀

$*$

ஜे

춘

苂

砶

골 
ฝัँ

$\because$

?

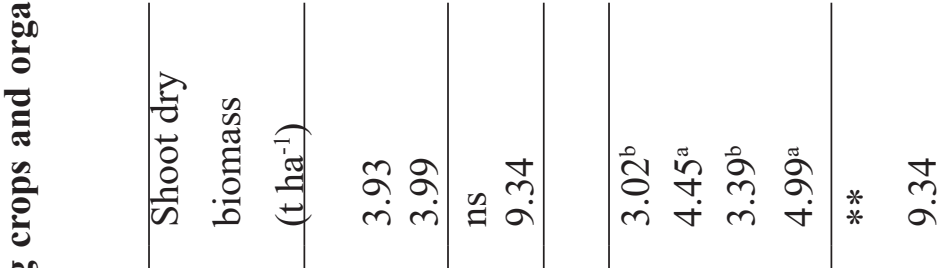

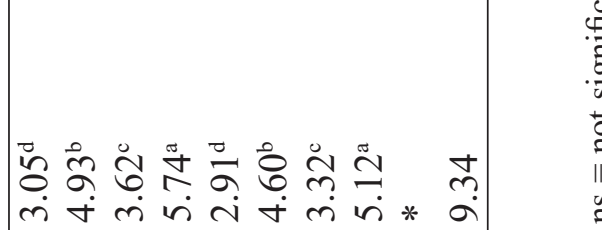

ำ ำ

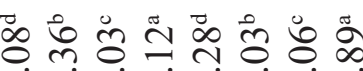

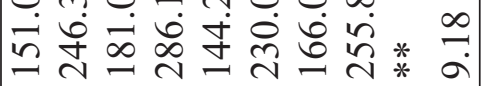

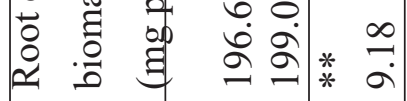

กิ

눈

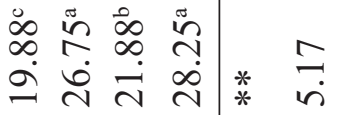

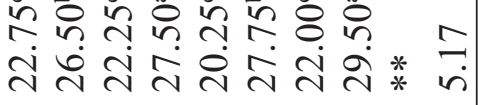

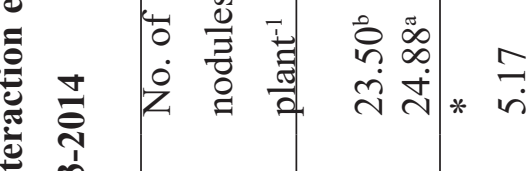

要

焉

莡

\#

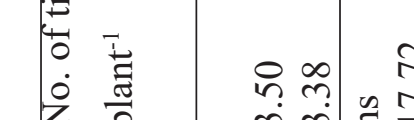

곤

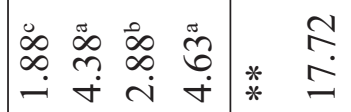

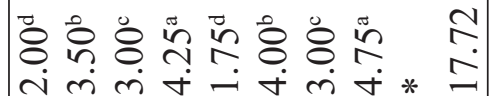

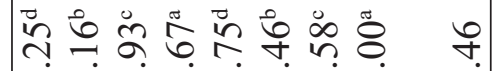

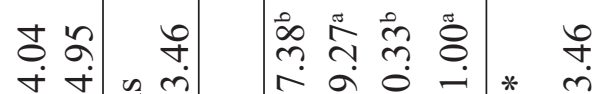

ஸे वंष्寸

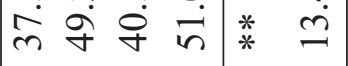

苛

0 .

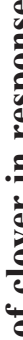

를

寸 $\dot{y} \cong$

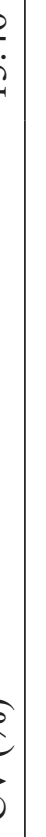

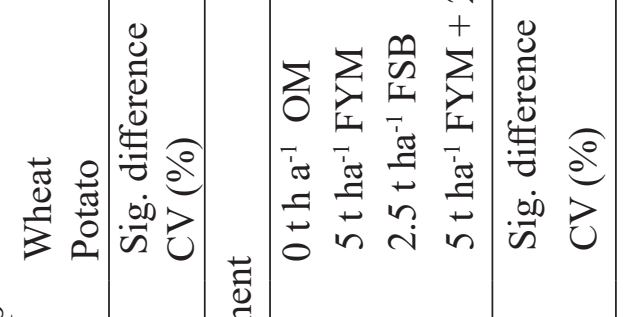

泀

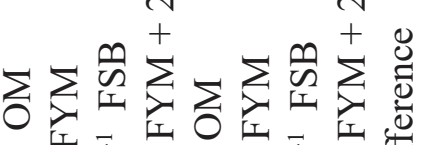

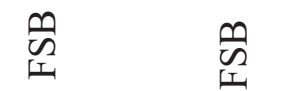

$\bar{\tau}$

苂








:อ

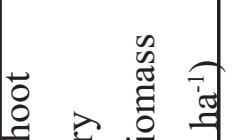

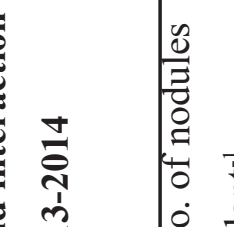

อ

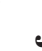

:

$\because$. 离 焉

|

ำ

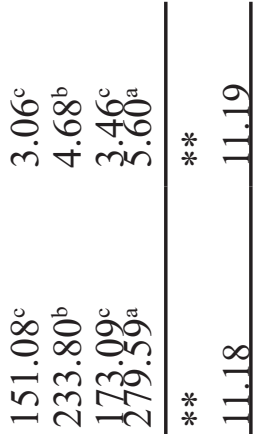

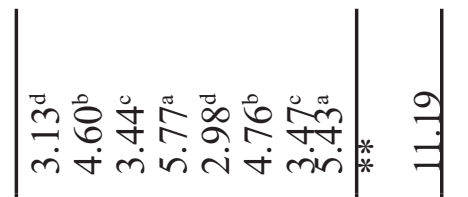

$\ddot{8}$

$\hat{\imath}$

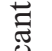

은

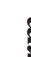

iñ

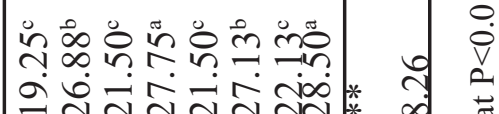

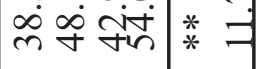

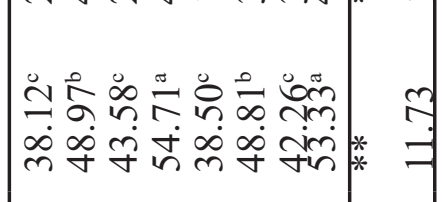

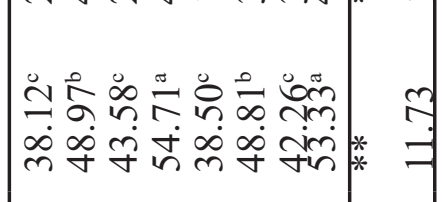

రํํ유

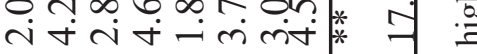
* *i:

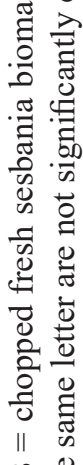




\section{Shoot and root dry biomass}

Unlike other growth parameters, the shoot and root dry biomass of clover showed significant difference due to the interaction effects of organic matter application and preceding crop at station conditions (Table 4). The highest shoot and root dry biomass of $6.7 \mathrm{t} \mathrm{ha}^{-1}$ and $334.08 \mathrm{mg} \mathrm{plant}^{-1}$ of clover, respectively was recorded using $5 \mathrm{tha}$ 1 FYM $+2.5 \mathrm{t} \mathrm{ha}^{-1}$ FSB and clover following wheat (Table 3). The lowest shoot and dry biomass of $3.05 \mathrm{t} \mathrm{ha}^{-1}$ and $151.08 \mathrm{mg} \mathrm{plant}^{-1}$ respectively was recorded when clover was preceded by potato and by the addition of 0 tha $^{-1}$ of FYM. This might be due to the larger amount of wheat biomass returned to the soil in previous years. However, the combined over site data showed that the shoot and dry biomass of clover significantly varied in response only to the different level of organic treatment. The highest shoot and dry biomass of $5.6 \mathrm{t} \mathrm{ha}^{-1}$ and $279.59 \mathrm{mg}$ plant $^{-1}$, respectively of clover were recorded $5 \mathrm{tha}^{-1} \mathrm{FYM}+2.5 \mathrm{tha}^{-1} \mathrm{FSB}$ in combined over sites. FYM at $5 \mathrm{t} \mathrm{ha}^{-1}$ showed shoot and root biomass of $4.68 \mathrm{t} \mathrm{ha}^{-1}$ and 233.80 $\mathrm{mg} / \mathrm{plant}$ of, respectively following the highest level. The lowest shoot and root dry biomass (3.06 $\mathrm{t} \mathrm{ha}^{-1}$ and $151.08 \mathrm{mg}$ plant $^{-1}$, respectively) were recorded on the untreated check (Table 5). FSB at $2.5 \mathrm{t} \mathrm{ha}^{-1}$ showed slightly higher dry shoot and root biomass of $3.46 \mathrm{t} \mathrm{ha}^{-1}$ and $233 \mathrm{mg} \mathrm{plant}^{-1}$, respectively, compared to the control (Table 5).
The increase in biomass yield of clover was due to the increases of soil nutrient at higher rate of organic treatment. The result is in agreement with previous studies that application of combinations of different manures sources improves the biomass yield of several crops. Farhad and Saleem (2009) observed that combinations of manure that holds 3 t ha ${ }^{-1}$ of cow manure and $2 \mathrm{t} \mathrm{ha}^{-1}$ of chicken manure significantly increased the dry weight of cowpea. Singh and Sinha ( 2001) identified that fresh and dry biomass yield of menthol mint increased by $23.4 \%$ through the use of green manure. Malligawad (2010) noted that application of organic manure significantly yielded higher fodder dry matter of $9.3 \mathrm{t} \mathrm{ha}^{-1}$ than the untreated control $\left(7.1 \mathrm{tha}^{-1}\right)$.

\section{Correlations}

Correlation analysis was also made between agronomic traits of clover (Table 6). Shoot dry biomass yield showed positive and significant correlation with plant height $\left(r=0.75^{* *}\right)$, number of nodules plant ${ }^{-1}\left(\mathrm{r}=0.78^{* *}\right)$, root biomass $(r=0.99 * *)$ and the number of tillers plant $^{-1}\left(r=0.75^{* *}\right)$. These results confirmed that growth parameters such as plant height, root dry weight, the number of nodules and tillers are best indicators to estimate total biomass production of clover. Strong correlation between nodule number and shoot dry biomass magnifies the contribution

Table 6: Correlation coefficients between agronomic parameters of clover

\begin{tabular}{llllll}
\hline $\begin{array}{l}\text { Growth } \\
\text { parameter }\end{array}$ & PH & TN & NN & RDW & SDBY \\
\hline PH & 1 & $0.60^{*}$ & $0.64^{*}$ & $0.75^{*}$ & $0.75^{*}$ \\
TN & & 1 & $0.72^{*}$ & $0.76^{*}$ & $0.75^{*}$ \\
NN & & 1 & $0.78^{* *}$ & $0.78^{* *}$ \\
RDW & & & 1 & $0.99^{* *}$ \\
DBY & & & & 1 \\
\hline
\end{tabular}

$\mathrm{PH}=$ plant height; $\mathrm{TN}=$ tiller number; $\mathrm{NN}=$ number of nodules; $\mathrm{RDW}=$ Root dry weight; $\mathrm{SDBY}=$ shoot dry biomass yield; ** = highly significant at $\mathrm{P}<0.01$ and $*=$ significant at $\mathrm{P}<0.05$. 
of bacterial association for better dry matter accumulation in legume species. The higher root dry matter also helps the plant to acquire ample nutrient and water for better biomass production. However, there is weak and none significant correlation between days to $50 \%$ flowering ( $\mathrm{r}=$ $0.07)$ and stand count $(\mathrm{r}=0.23)$. The probable reason may be less number of stand count might be compensated by an increase in number of tiller.

The study summarized that plant height, the number of nodules plant ${ }^{-1}$, root dry weight and tiller number plant $^{-1}$ were the most important variables to be considered to estimate the biomass yield of clover in Guagusa District Administrative Zone.

\section{CONCLUSIONS}

The study reveals that only the main effect of organic treatment significantly affected the biomass yield of clover. Biomass yield was highest at the highest level of organic treatment, intermediate at intermediate level of organic treatment and low on unfertilized control. Thus, the highest total dry biomass $(5.60 \mathrm{t}$ ha $\left.{ }^{1}\right)$ clovers was recorded at $5 \mathrm{t} \mathrm{ha}^{-1} \mathrm{FYM}+2.5$ $\mathrm{t} \mathrm{ha}^{-1}$ FSB whereas the unfertilized control showed the lowest mean dry biomass $(3.06 \mathrm{t}$ ha 1 ) of clover compared to all other treatments. FYM at $5 \mathrm{t} \mathrm{ha}^{-1}$ showed shoot biomass (4.68 t $\mathrm{ha}^{-1}$ ) of clover following the highest level of treatments. In addition, plant height and the number of modules plant ${ }^{-1}$ and of tillers plant $^{-1}$ were highest at the highest level of organic treatment. In general, the result demonstrated that the combination of manure improved the biomass yield of clover without reduction in yield potential. Maximum yield was achieved by application of high level of organic treatment.
The finding also solves the challenges of over relying of the community on synthetic fertilizer. Growers experience escalating price, diminishing farm returns, soil acidity and water quality deterioration upon heavy use of synthetic fertilizer for decades. However, tending to organic soil fertility management system solves the challenges of synthetic fertilizer that farmers currently face. Organic fertilizer is less costly, environmentally less hazardous and more profitable compared to synthetic fertilizer.

Hence, the results of this study suggest that Combination of manure, FYM at $5 \mathrm{t} \mathrm{ha}^{-1}+\mathrm{FSB}$ at $2.5 \mathrm{t} \mathrm{ha}^{-1}$ could be recommended for better biomass yield of clover for Awi Administrative Zone and other similar agro-ecological areas.

\section{ACKNOWLEDGMENTS}

The authors wish to acknowledge The Agricultural Research for Development (ARD) Dimension of European Research Area (ERA) for funding the project.

\section{REFERENCES}

Abebe Zerihun, Sharma, J., Dechasa, N. and Kanampiu, F. (2013). The effect of integrated organic and inorganic fertilizer rates on performances of soybean and maize component crops of a soybean/maize mixture at Bako,Western Ethiop. African Journal of Agricultural Research 8(29):3921-3929.

Adeoye, P., Adebayo, S. and Musa, J. (2011). Growth and yield response of cowpea to poultry and cattle manure as amendments on sandy loam soil plot. Agriculture Journal 6(5): 218 221. 
ANRS-BoFED (2006). Amhara Region Bureau of Finance and Economic Development Annual Statistical Bulletin. Bahir Dar, Ethiopia.

Angus, J., Kirkegaard, J. and Peoples, M. (2001). Rotation sequence and phase: research on crop and pasture systems. In Poceedings $\mathbf{1 0}^{\text {th }}$ Australian Agronomy Conference: 22452251, Australian, Melbourne.

Armstrong, R., Cocker, K., Johnson, S., Walsh, K., Miller, G., Kuskopf, B., Standley, J. and Probert, E. (1999). Legume and opportunity cropping systems in central Queensland: Legume growth, nitrogen fixation, and water use. Australian Journal of Agricultural Research 50(6): 909 924.

Bilal, Q., Muhammad, Y. and Sajjad, A. (2000). Effect of varying levels of nitrogen and farmyard manure application on tillering and height of mott grass. Inernational Journal of Agriculture \& Biology 2(1): 21-23.

Black, C. and Allison, L. (1965). Methods of Soil Analysis. Newyork,USA.

Bouyoucos, S. (1962). Hydrometer method improved for making particle size analysis of soils. Agronomy Journal 54(5): 464-465.

Carl, J., Rosen, L.and Deborah, A. (2007). Exploring the benefits of organic nutrient sources for crop production and soil quality. Hort Technology 17(4): 422-430.

Dalal, R. and Mayer, J. (1990). Long-term trends in fertility of soils under continuous cultivation and cereal cropping in southern Queensland: available nitrogen indices and their relationships to crop yield and n uptake. Australian Journal of Soil 12(28): 563-575.

Farhad, W., Saleem, M., Cheema, C. and Hammad, M. (2009). Effect of poultry manure levels on the productivity of spring maize. The Journal of Animal and Plant Sciences 19(3): 122-125.

Hazelton, P. and Murphy, B. (2007). Interpreting Soil Test Results. CSIRO Publishing, Millburn, Australia.

Hellal, F., Zewainy, R., Khalil, A. and Ragab, M. (2014). Effect of organic and bio-fertilizer aanagement practices on nutrient availability and uptake by faba bean- maize sequence. American-Eurasian Journal of Sustainable Agriculture 8(5): 35-42.

Konthoujam, N., Tensubam, B., Herojit, S., Athokpam, N. and Diana, S. (2013). Influence of inorganic, biological and organic manures on nodulation and yield of soybean and soil properties. Australian Journal of Crop Science 7(9):1407-1415.

Kumar, R. and Hiremath, S. (2015). Residual effects of maize hybrids, plant population and fertility levels on performance of chickpea in maize - chickpea cropping sequence. Karnataka Journal of Agricultural Sciences 28(4): 482485.

Lupway, L. and Girma, A. (2010). Nutrient content of cattle manure from small scale farms and experimental stations of Ethiopian. Agriculture, Ecosystems and Environment 78(2000): 57-63.

Madukwe, D., Christo, I. and Onuh, M. (2008). Effects of organic manure and cowpea varieties on the chemical properties of the soil and root nodulation. Science World Journal 3(1): 43-46.

Malligawad, L. (2010). Effect of organics on the productivity of groundnut and its residual effects on succeeding safflower under rain-fed farming situations. In:19 ${ }^{\text {th }}$ World Congress Of Soil Science, Soil Solutions For A Changing World, Australia. Published on DVD.

McLean, E. (1965). Methods of Soil Analysis. America,Madison. 
Olsen, S., Cole, C. and Watanabe, F. (1954). Estimation of available phosphorus in soils by extraction with sodium bicarbonate. European Journal of Agronomy 939( 24): 26-30.

Otieno, P., Muthomi, G., Chemining, W. and Nderitu, J. (2009). Effect of rhizobia inoculation, farmyard manure and nitrogen fertilizer on nodulation and yield of food grain legumes. Journal of Biological Sciences 4(9): 326-332.

Scotti, R., Bonanomi, G., Scelza, R., Zoina, A. and Rao, M. (2015). Organic amendments as sustainable tool to recovery fertility in intensive agricultural systems. Journal of Soil Science and Plant Nutrition 15(2): 333-352.

Singh, B. and Sinha, S. (2001). Effect of integrated nutrient management on a typical haplaquant on yield and nutrient availability in a ricewheat cropping system. Australian Journal of Agricultural Research 52(8): 607.

Sulfab, H. (2010). Effect of organics on the productivity of groundnut and its residual effects on succeeding safflower under rain-fed farming situations. In: $19^{\text {th }}$ World Congress of Soil Science, Soil Solutions for a Changing World, Australia. Published on DVD.

Sulfab, H. (2013). Effect of bio-organic fertilizers on soil fertility and yield of groundnut in malakal area, republic of south sudan. Journal of Natural Resource 3(1): 14-19.

Tadesse Tsegaye (1991). Soil, Plant, Water, Fertilizer, Animal Manure And Compost Analysis. Addis Ababa, Ethiopia.

Tarkalson, D., Jolley, D., Robbins, C. and Terry, E. (1998). Mycorrhizal colonization and nutrient uptake of dry bean in manure and compost manure-treated subsoil and untreated topsoil and subsoil. Journal of Plant Nutrition 21(9): 120.
Walkley, A. and Black, A. (1934). An examination of degtjareff method for determining soil organic matter and a proposed modification of the chromic acid titration method. Agricultural Sciences 8(3): 29-37.

Yihenew Gebresilassie (2002). Selected Chemical and Physical Characteristics of Soils of Adet Agricultural Research Center and its Testing Sites. Ethiopia Journal of Neutral Resource (4):203-206.

Yolcu , H., Gunes, A., Dasci, M., Turan, M. and Serin, Y. (2011). The effects of solid, liquid and combined cattle manure applications on the yield, quality and mineral contents of common vetch and barley intercropping mixture. Ausrralia Journal of Science 5(13): 1730-173.

Zingore, S. (2011). Maize productivity and response to fertilizer use as affected by soil fertility variability, manure application, and cropping system:reilance of agriculture system againest crisiseilance of agriculture system againest crisis. Information Agriculture Conference, July 12-14. 